\title{
WATER CONSUMPTION OF SHADE EXPERIMENTAL FIELD MAINTAINED AS A REPEAT CROP IN DIFFERENT IRRIGATION REGIMES
}

\section{S.O.Khusanov}

"Deputy Director Of The Andijan Branch Of The Forestry Research Institute", Andijan, Uzbekistan

\section{G.B. Turgunova}

Doctoral Student Andijan Institute Of Agriculture And Agrotechnology, Andijan Region, Uzbekistan

The article contains information on water consumption in the field of experience of soybeans grown as a product that is repeated in various irrigation procedures.

\section{ABSTRACT}

The article examines the water consumption for harvesting 1 centner of soybean variety "Tomaris", grown as an auxiliary crop, under various irrigation regimes.

KEYWORDS: - Shade, re-sowing, shadow variety "Tomaris", LFHC, pre-irrigation soil moisture, irrigation rate, seasonal irrigation rate, duration of irrigation, irrigation schedule, water balance, water consumption, soil moisture reserve.

\section{INTRODUCTION}

The role of irrigation water in agricultural production and food security around the world is invaluable. According to the International Food and Agriculture Organization (FAO), in 2020 the world gross harvest of oilseeds is projected to grow at the level of the world population.

Correct determination of the norms and terms of watering the shade, taking into account the soil and climatic conditions, depending on the physiological requirements of the plant, has a positive effect on the quantity and quality of the resulting grain.

\section{THE MAIN FINDINGS AND RESULTS}

In recent years, the country has achieved high yields as a result of the correct selection of soybean varieties for various soil and climatic conditions, as well as the development and application of agricultural techniques for growing soybeans with high yields and grain quality. One of the important tasks of the Strategy for the Development of Agriculture of the Republic of Uzbekistan for 2020-2030 is "ensuring the use of intensive methods in agricultural production, primarily modern agricultural technologies that save water and resources." 
CURRENT RESEARCH JOURNAL OF HISTORY 2(8): 06-09, August 2021

DOI: https://doi.org/10.37547/history-crjh-02-08-02

ISSN 2767-472X

(C)2021 Master Journals

\section{Crossref do) 81 Google}

Accepted 04 ${ }^{\text {th }}$ August, 2021 \& Published 09th August, 2021

Based on the above, in 2017-2019. Field experiments were carried out in order to develop optimal shade irrigation regimes and obtain scientific conclusions in the conditions of meadow soils of the Andijan region.

In the territories freed from winter wheat, the soil moisture before irrigation of the Tomaris variety as a secondary crop is about $65-70-65 \%$, $70-75-65 \%$ and $75-80-70 \%$ in relation to the LFHC, Research Institute of grain and leguminous crops carried out in the conditions of meadow soils. In the experiment, there was 1 option 9.6 meters wide, 50 meters long, the area of each section is $480 \mathrm{~m} 2$, the calculated area is $240 \mathrm{~m} 2$, in four turns, in one tier.

Over the years of the experiment, the inflow and outflow of water from the experimental field was monitored. The water balance consists of the input and output parts of the water norm, set during the shelf life of the plant. The water balance of the field is made up of the norm of water used for irrigation of the water intake part, precipitation during the period of operation, and groundwater. The water balance of the field consists of the evaporation of water from the soil during the application period, water used for transpiration by plants, water disturbed in the lower soil layers as a result of excessive irrigation, and irrigation water leakage to other territories and water assimilated by plants.

Over the years of the experiment, samples were taken to determine the moisture reserve from the $0-170 \mathrm{~cm}$ layer of the soil of the experimental field at the beginning and end of the application period for the study of the water intake part of the experimental field, precipitation during the period of application and seasonal irrigation rates used for irrigation. The income part of water consumption was studied according to the following formula.

$$
\mathrm{E}=\mathbf{N}_{\mathrm{H}}-\mathbf{W}_{\mathrm{K}}+\mathbf{O}+\mathbf{M}_{\mathbf{0}}
$$

Here: total water consumption of the E-test field, m3 / Moisture reserve at the beginning of the application period in the soil layer $\mathrm{NH}-0-170 \mathrm{~cm}$, m3 / WK - moisture reserve at the end of the application period in the soil layer $0-170 \mathrm{~cm}, \mathrm{~m} 3$ /;0- Total precipitation for the period of operation, m3 /;MO - Seasonal irrigation rate, m3 /;

The results of scientific research on water consumption for harvesting 1 centre of grain, depending on the irrigation regime of soybean varieties by years, are shown in Picture 1 . 
CURRENT RESEARCH JOURNAL OF HISTORY 2(8): 06-09, August 2021

DOI: https://doi.org/10.37547/history-crjh-02-08-02

ISSN 2767-472X

(C)2021 Master Journals

Crossref do: 81 Google

Accepted 04th August, 2021 \& Published 09th August, 2021

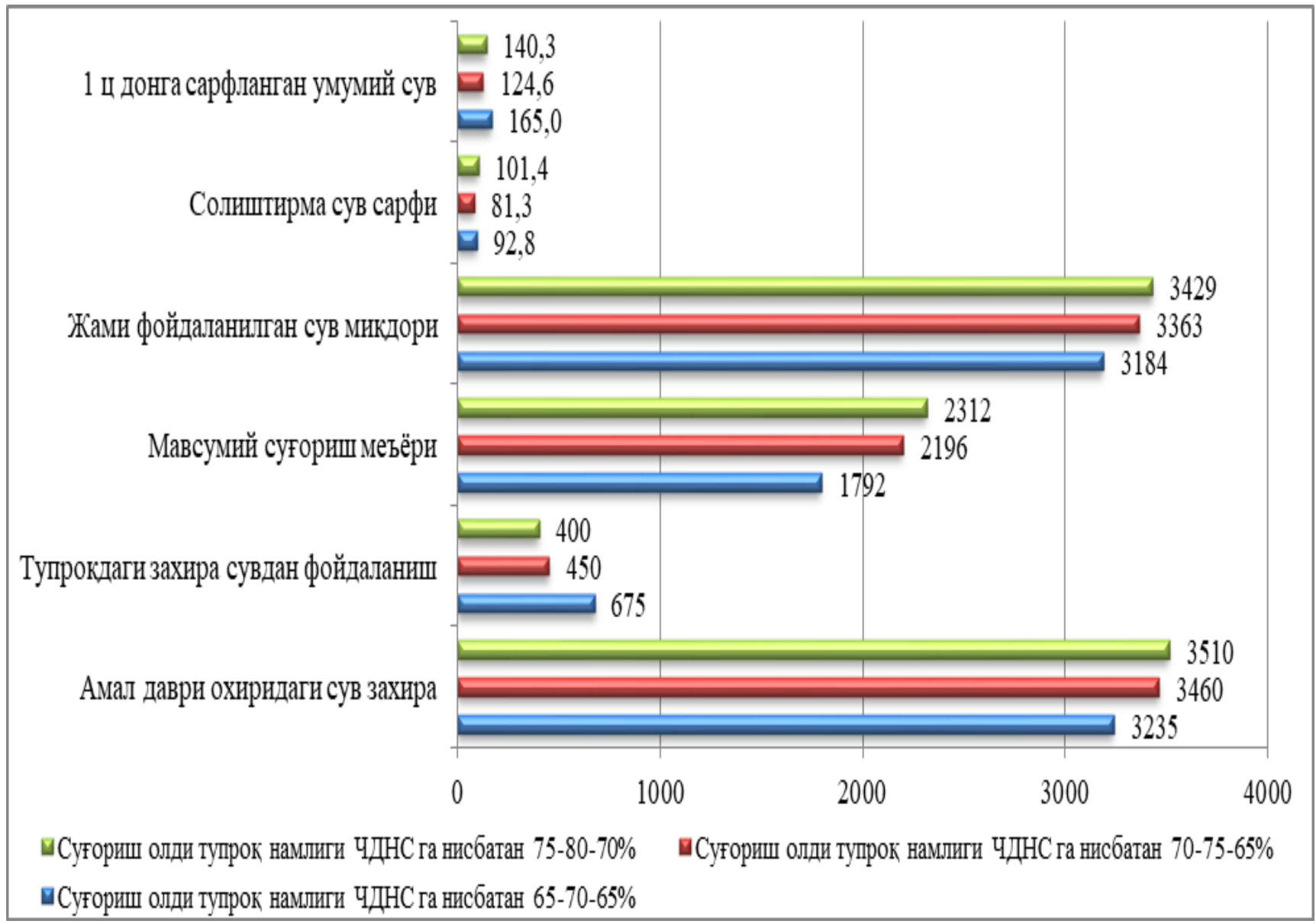

Picture 1. Water consumption for harvesting 1 centner of Tomaris soybean cultivated as a secondary crop, (m3 /) 2017

According to the Andijan branches of Uzhydromet, the amount of precipitation during the shadow period, grown in 2017 as a secondary crop, was $71.7 \mathrm{~mm}$. Soybean grain yield before irrigation, soil moisture $65-70-65 \%$ in relation to LFHC is about $19.3 \mathrm{c} /$ soil fertility before irrigation is about $70-75-65 \%$ in relation to LFHC, version 27.0. c / ha nei It was found that the variant with irrigation of the order of 80 $70 \%$ was $22.8 \mathrm{c} /$.
According to the results of our research in 2017, at the beginning of the application period, the moisture reserve of the experimental field was $3910 \mathrm{~m} 3 /$. The pre-irrigation soil moisture in the order of irrigation is about $65-70-65 \%$ compared to the LFHC by the end of the period the moisture reserve in the soil decreased by $3235 \mathrm{~m} 3$ / the use of the moisture reserve in the soil $675.0 \mathrm{~m} 3$ / external Seasonal irrigation rate $1792 \mathrm{~m} 3$ /. The volume of water used was 3184 $\mathrm{m} 3$ /specific water consumption - $92.8 \mathrm{~m} 3$ / ha total water consumption per 1 center of grain $165.0 \mathrm{~m} 3 /$. 
CURRENT RESEARCH JOURNAL OF HISTORY 2(8): 06-09, August 2021

DOI: https://doi.org/10.37547/history-crjh-02-08-02

ISSN 2767-472X

(C)2021 Master Journals

Crossref dof 81 Google

Accepted 04th August, 2021 \& Published 09th August, 2021

Pre-irrigation soil moisture in the order of irrigation is about $70-75-65 \%$ compared to LFHC

. By the end of the period, the moisture reserve in the soil decreased by $3460 \mathrm{~m} 3$ / the use of the moisture reserve in the soil was $450 \mathrm{~m} 3$ /.The seasonal irrigation rate is $2196 \mathrm{~m} 3$ / the water consumption is $3363 \mathrm{~m} 3$ / ha the specific water consumption is $81.3 \mathrm{~m} 3$ / and the total water consumption per centner of grain is $124.6 \mathrm{~m} 3 /$. By the end of the application period, the moisture reserve in the soil decreased by 3510 $\mathrm{m} 3$ / the use of the moisture reserve in the soil was $400 \mathrm{~m} 3 /$ and $400 \mathrm{~m} 3 /$. The seasonal irrigation rate was $2312 \mathrm{~m} 3$ / the amount of water used was $3429 \mathrm{~m} 3$ / the specific water consumption was $101.4 \mathrm{~m} 3$ / and the total water consumption per centner of grain was $140.3 \mathrm{~m} 3$ /.

\section{Conclusion}

According to the results of the study, the smallest water consumption and high yield of the soybean variety "Tomaris", cultivated as a secondary crop, was obtained with soil irrigation.

\section{ReFERENCES}

1. Resolution of the President of the Republic of Uzbekistan dated March 14, 2017. Resolution PQ-2832 "On measures to increase soybeans and soybeans in the republic in 2017-2021"

2. Recommendations on "Shadow generation in the country based on innovative technologies" - Andijan-2018, 4 p.

3. World news in the field of agro-industrial complex and agriculture. Ministry of Agriculture of the Republic of Uzbekistan, Analytical Day, June 18, 2020 p-27-28. 